\title{
ORGANIC GRISSINI WITH ORGANIC DILL POWDERS - INNOVATIVE PRODUCTS
}

\author{
Nela Dragomir ${ }^{1, *}$, Carmen Georgeta Nicolae ${ }^{1}$, Oana-Crina Bujor ${ }^{2}$, \\ Elisabeta Elena Popa ${ }^{3}$, Petre Andrei ${ }^{2}$, Liliana Badulescu ${ }^{2,4}$ \\ ${ }^{1}$ Faculty of Animal Productions Engineering and Management, University of Agronomic Sciences and Veterinary \\ Medicine of Bucharest, 59 Marasti Blvd, District 1, Bucharest, Romania \\ ${ }^{2}$ Research Center for Studies of Food Quality and Agricultural Products, University of Agronomic Sciences and \\ Veterinary Medicine of Bucharest, 59 Marasti Blvd, District 1, Bucharest, Romania) \\ ${ }^{3}$ Faculty of Biotechnologies, University of Agronomic Sciences and Veterinary Medicine of Bucharest, 59 Marasti \\ Blvd, District 1, Bucharest, Romania \\ ${ }^{4}$ Faculty of Horticulture, University of Agronomic Sciences and Veterinary Medicine of Bucharest, 59 Marasti Blvd,
} District 1, Bucharest, Romania

\begin{abstract}
The dill (Anethum graveolens L.) is an annual herbaceous plant, which has spread widely in Romanian cuisine and is used entirely: leaves, stem, and seeds. It contains active substances with multiple beneficial properties for human health. The aim of this study was to develop new type of grissini, enriched with powder organic dill obtained from leaves and stems. The organic powders were realized in the framework of SusOrgPlus project in the Research Center for Studies of Food Quality and Agricultural Products, University of Agronomic Sciences and Veterinary Medicine of Bucharest. Grissini's with different percentage of leaf powder organic dill and stem powder organic dill were designed and evaluated in a consumer acceptance test, where the aroma, color, flavor and appearance of the attributes were evaluated. The most valuable products with the highest acceptance scores were selected, further analyzed in an accelerated stability study at different temperatures. The new developed food product enriched with powder from organic stem dill is a healthy alternative snack, with the potential to raise awareness and encourage the consumption of organic products.
\end{abstract}

Keywords: added value, consumer acceptance, hedonic scale, new product, taste.

\section{INTRODUCTION}

Anethum graveolens L. (Umbelliferae), commonly known as dill, is native to Mediterranean countries and southeastern Europe. This plant grows easily and has good productivity. Fresh and dried dill leaves are widely used as herbs in Europe and central Asia, and part of the Romanian culinary tradition. Dill is an important aromatic herb, used for flavoring of various foods, such as salads, sauces, soups, sea foods, in pickles and different bakery products. Additionally, dill leaves are also used as dried (Isbilir and Sagiroglu, 2011). Dill fresh and dried leaves called dill weed are used as condiment and tea. The leaves of the dill contain phosphorus, potassium, and magnesium minerals (Jana and Shekhawat, 2010).

Various different compounds have been isolated from the seeds, leaves and inflorescence of this plant; 17 volatile compounds have been identified. The main constituents of dill oil which is pale 
yellow in colour, darkens on keeping, with the odour of the fruit and a hot, acrid taste are a mixture of a paraffin hydrocarbon and 40 to $60 \%$ of d-carvone $(23.1 \%)$ with d-limonene $(45 \%)$. It also consists of $\alpha$-phellandrene, eugenol, anethole, flavonoids, coumarins, triterpenes, phenolic acids and umbelliferones. The fruit yields about $3.5 \%$ of the oil; its specific gravity varies between 0.895 and 0.915 (Jana and Shekhawat, 2010). Dill is a medicinal herb, also widely used in the food industry for flavoring foods and beverages due to its pleasant spicy aroma. It has been proven that the essential oil of dill has antimicrobial, antifungal, and antioxidant activity (Najaran et al., 2016).

Dill can be used in other fields. Anethum graveolens, is a rich aromatic plant with the phenolics contents, where the seeds are advised to be more explored, whereas the soil salinity increase significantly the phenolic contents in the plant and seeds. Also, dill could be one of the best ecofriendly fungicides (Zeyneb et al., 2019).

Many researches showed that it is possible to formulate acceptable gluten-free biscuits and another bakery product using alternative flours from cereals, pseudocereals and legumes that may also enhance the nutritional quality, the antioxidant activity and the glycemic index of the grissini (Ferreira et al., 2015; Di Cairano et al., 2018; Bahaciu et al., 2019).

The dehydration, by controlled methods, of different parts of the plant, aims at the most preservation of its sensorial and physico-chemical properties. The organic product can be stored for an extended period of time and incorporated into various products to enrich their aromatic profile (Kruma et al., 2011).

\section{MATERIALS AND METHODS}

In the study were used organic dill powders (leaves and stems) as research materials. The organic ingredients used were obtained at the Research Center for Studies of Food Quality and Agricultural Products of USAMV Bucharest, with support of the SusOrgPlus project: Intelligent food processing chains \& natural additives and colourants, which aims to develop advanced processing technologies for organic products and by-products (Bujor-Neniță and Bădulescu, 2019). The aim of the study is to use of these organic ingredients in a new grissini recipe, the qualitative and sensory evaluation of the obtained products (ISO 6658:2005), and the analysis of the degree of consumer acceptance for the organic food products enriched with food additives and natural dyes.

The working methodology consisted in: the development of the formula of grissini enriched with organic powders from dill (leaves and organic powders from dill stem) (Dragomir and Nicolae, 2019).

In order to highlight the sensory changes of the addition of dill powder, 3 samples were formed, respectively: S0 control sample (without powder), S1 - 1\% organic dill powder (respectively $0.5 \%$ dill leaf powder and $0.5 \%$ dill stem powder) and S2 - $2 \%$ organic dill powder (respectively $1 \%$ dill leaf powder and $1 \%$ dill stem powder) (Table 1). The consumer acceptance was done using scores on a 5-point Hedonic scale. Nutrient content it was calculated using a nutritional development tool, Softmedia program (http://softfedima.ro/).

\section{RESULTS AND DISCUSSIONS}

The obtaining technology of Grissini enriched with organic dill powder has been adapted according to the natural organic powder added. Leaves and stems of dill are used for food, because of their typical taste and aroma. That are the main objective of the study.

For the Grissini enriched with organic dill powder, there were used the following ingredients: organic whole wheat bread flour, water, organic virgin sunflower oil, organic unrefined brown 
sugar from sugar cane, salt, dry yeast and organic powders from dill (leaves and stem) (Table 1).

Table 1. Grissini enriched with organic dill powder

\begin{tabular}{|l|c|c|c|}
\hline Specification & \multicolumn{3}{|c|}{ Sample } \\
\hline Ingredients & S0 & S1 & S2 \\
\hline Organic whole wheat bread flour, g & 500 & 500 & 500 \\
\hline Water, ml & 250 & 250 & 250 \\
\hline Organic virgin Sunflower oil, ml & 60 & 60 & 60 \\
\hline Organic unrefined brown sugar from sugar cane, g & 20 & 20 & 20 \\
\hline Salt, g & 12 & 12 & 12 \\
\hline Dry yeast organic, g & 9 & 9 & 9 \\
\hline Organic powder dill, \% & 0 & 1 & 2 \\
\hline Organic dill leaves powder, \% & - & $0.5 \%$ & $1 \%$ \\
\hline Organic dill stem powder, \% & - & $0.5 \%$ & $1 \%$ \\
\hline
\end{tabular}

All ingredients were purchased from retail specialty store, except organic dill powders, which were realized in the framework of the SusOrgPlus project at the Research Centre for Studies of Food Quality and Agricultural Products, University of Agronomical Sciences and Veterinary Medicine of Bucharest.

The technology includes the following steps: Preparation of yeast: the yeast is mixed with unrefined brown sugar, with $10 \%$ hot water and left to activate for 30 minutes; Wholemeal wheat flour is sifted and brought to room temperature; The powder from dehydrated dill stalks is hydrated in 100 $\mathrm{ml}$ of warm water. Add sifted flour, active yeast and water to the mixer, then mix for 3-4 minutes when the cold-pressed sunflower oil is also encouraged. Kneading is considered complete when the dough becomes homogeneous, shiny on the surface and is tightened on a spiral mixture at the mixer. The dough is covered and leavened for 60 minutes at $35^{\circ} \mathrm{C}$ at a relative humidity of $65 \%$; Modelling consists in rolling the dough to a thickness of $1 \mathrm{~cm}$, then portion with $1 \mathrm{~cm}$ thick and 10 $\mathrm{cm}$ long. Place the strips of dough on a baking sheet, grease with oil and leave to rest for 20 minutes at room temperature. The baking is done at $200^{\circ} \mathrm{C}$ for $10-12$ minutes; the product is cooling to room temperature.

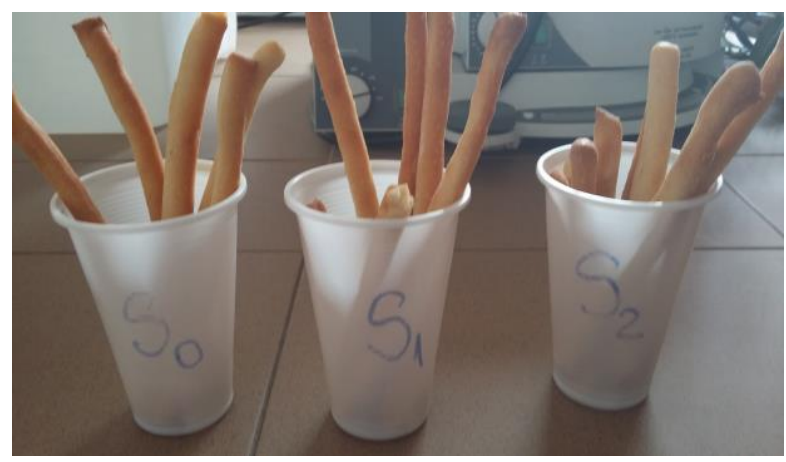

Figure 1. Grissini with organic dill powders (leaves and stem):

SO - control sample, S1 - $1 \%$ organic dill powder, $S 2$ - $2 \%$ organic dill powder

Grissini enriched with organic dill powders come in the form of crumbly and crispy bars, with original and pleasant taste, specific to dill, golden color (Figure 1). It is recommended to be eaten simple as snacks or in combination with various dishes. By lyophilization, the dill retains the 
characteristics intense colour and flavour.

Sensorial evaluation. The panel group consisting of 30 members, of different ages, was chosen to determine the level of acceptance of grissini enriched with organic dill powders. The panel members were asked to evaluated the sensorial characteristics and note products using a five-point in Hedonic Scale, with corresponding descriptive terms ranging from 5 "like extremely" to 1 "dislike extremely" (Figure 2 and Figure 3). The sensorial tests of the flavour Grissini enriched with organic dill powder were made considering: appearance, forma, colour, and smell, overall taste of the sample (ISO 6658:2005).

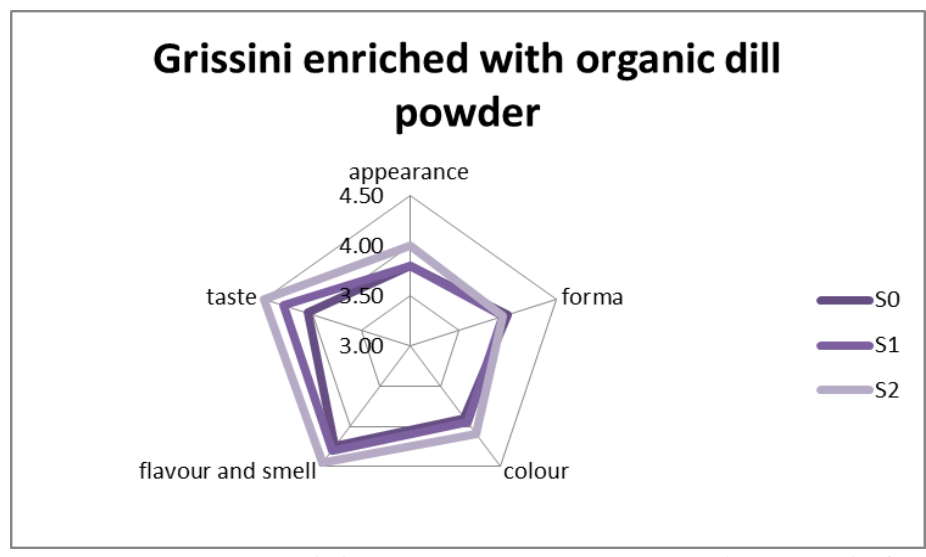

Figure 2. Consumer acceptability scores on a 5-point Hedonic scale for grissini

Addition of organic dill powders influenced the taste (for $\mathrm{S} 0$ is 4.05 , for $\mathrm{S} 1$ is 4.3 and for $\mathrm{S} 2$ is 4.5 ), flavour and smell (for S0 is 4.25, for S1 is 4.3 and for S2 is 4.45), and to a lesser extent colour. The colour on the S2 was darker, but was more appreciated by the consumer. Overall, the S2 test was the most appreciated, receiving a grade of 4.2 compared to S0 with 4.05 (Figure 3 ).

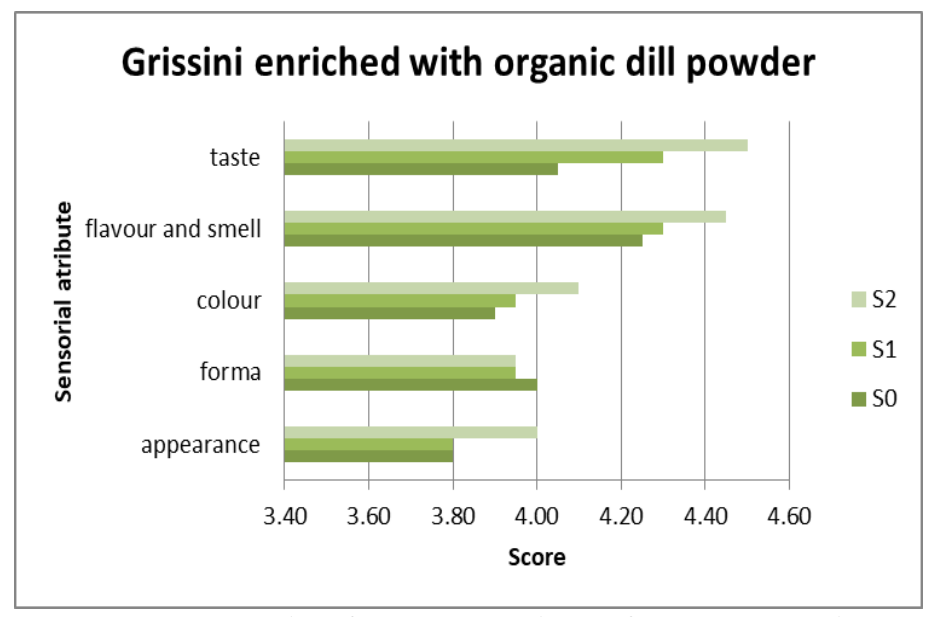

Figure 3. Results of sensory analysis of grissini samples

The results showed that there is a significant difference in taste and flavour and smell at S2 sample where it was added $2 \%$ organic powders from dill (leaves and stem). Organoleptic characteristic of produced grissini (forma, colour, taste, flavour and smell, general appearance and total score) at different levels of organic powders from dill (leaves and stem) was presented in Figure 4. 


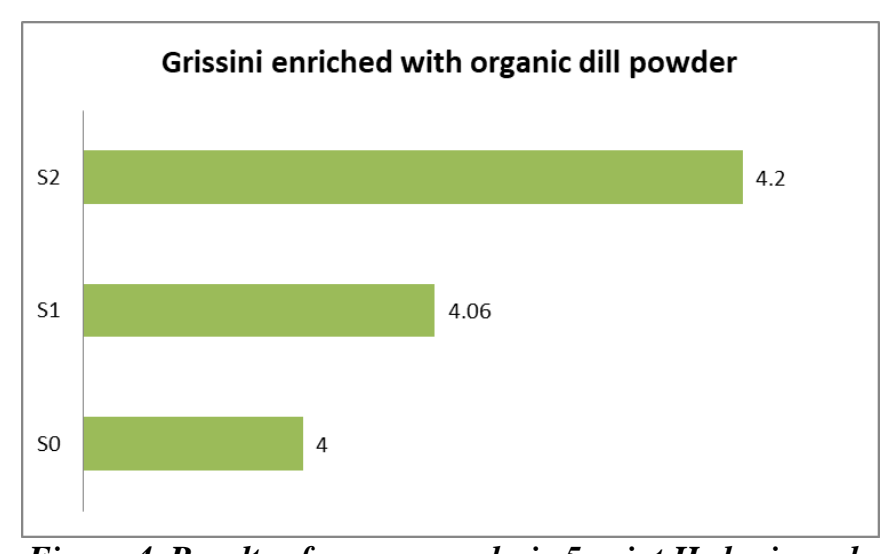

Figure 4. Results of sensory analysis-5 point Hedonic scale

Nutritional composition. Nutritional composition it was calculated using a program nutritional development tool, Softmedia programme (http://softfedima.ro/). Softmedia programme makes it easy to prepare a nutrition facts panel, nutrition data sheet, ingredient statement for any food product. Formulas can be adjusted for moisture and/or fat content. Information can be printed, saved as a PDF document. In terms of energy value, the values have not changed very much. For the calculation of the nutritional value, losses in baking and cooling of $10 \%$ were taken into account.

The table 2 shows the nutritive value of Grissini enriched with organic dill powder of different percent i.e. control (S0) without incorporation of organic dill powder and with incorporation of $1 \%$ organic dill powder (S1) and 2\% organic dill powder (S2). The content in fat, protein and salt of all three samples was the same.

Table 2. Nutritional values for $100 \mathrm{~g}$ Grissini enriched with organic dill powder

\begin{tabular}{|l|c|c|c|}
\hline Specification & \multicolumn{3}{|c|}{ Sample } \\
\hline Nutrient / samples & S0 & S1 & S2 \\
\hline \multirow{2}{*}{$\begin{array}{l}\text { Energy kJ } \\
\text { Kcal }\end{array}$} & 1250.3 & 1249.4 & 1249.4 \\
\cline { 2 - 4 } & 297.9 & 297.7 & 297.7 \\
\hline Fat, g & 9.1 & 9.1 & 9.1 \\
\hline of which saturated fatty acids & 1.5 & 1.5 & 1.5 \\
\hline Carbohydrates, g & 41.9 & 41.8 & 41.8 \\
\hline of which sugars & 3.2 & 3.2 & 3.2 \\
\hline Fiber, g & 8.8 & 8.9 & 8.9 \\
\hline Protein, g & 7.7 & 7.7 & 7.7 \\
\hline Salt, g & 1.6 & 1.6 & 1.6 \\
\hline
\end{tabular}

The result revealed that the carbohydrate content decreased with the increase in amount of organic dill powder. The carbohydrates were $41.9 \mathrm{~g}$ in S0, and $41.8 \mathrm{~g}$ in S1 and S2; the energy was found highest in S0 $(297.9 \mathrm{Kcal})$. The table shows that the addition of organic dill powder brings fiber. Dill leaves are rich source of dietary fibers, minerals sand vitamins.

\section{CONCLUSIONS}

Sensory Analysis tests have shown a differentiated influence of SusOrgPlus organic ingredients in 
the quality of food. The use of organic dill powders (leaves and stems), obtained in the SusOrgPlus project at the Research Centre for Studies of Food Quality and Agricultural Products, USAMV Bucharest, to obtaining Grissini enriched with organic dill powder, has increased sensory value and it was accepted by consumers. It is concluded that organic dill powders (leaves and stems) can be successfully incorporated in the development of nutritious grissini which have good sensory acceptability. As there were no significant differences in the sensory quality of grissini with organic dill powders (leaves and stems), it can to use higher dosages of powder from dehydrated stems and dill leaves in the product formula.

\section{ACKNOWLEDGEMENTS}

The authors acknowledge the financial support for this project provided by transnational funding bodies, being partners of the H2020 ERA-net project, CORE Organic Cofund, and the cofund from the European Commission. This work was supported by a grant of the Romanian Authority for Scientific Research and Innovation, CCCDI - UEFISCDI, project number 4/2018 ERANET-COREORGANIC SusOrgPlus, within PNCDI III.

\section{REFERENCES}

Bahaciu, G.V., Dragomir, N., Defta, N., Nicolae, C.G. (2019). Study regarding consumers behaviour towards innovative confectionery products. Scientific Papers. Series D. Animal Science, LXII (1), 404-409.

Bujor-Nenița, O., Bădulescu, L. (2019). Valorificarea produselor agroalimentare ecologice pentru obținerea de produse naturale cu valoare nutritivă ridicată [Valorization of ecological agri-food products for obtaining natural products with high nutritional value]. Workshop"Ecologic pentru sănătatea noastră”, Bio Life \& Style 2019, Expoziţie pentru o viaţă verde. Bucharest, RO: Ex Terra Aurum \& INVEL-Multimedia Publishing Houses, ISBN 978-606764-051-9.

Di Cairano, M., Galgano, F., Tolve, R., Caruso, M.C., Condelli, N. (2018). Focus on gluten free biscuits: Ingredients and issues. Trends in Food Science \& Technology, 81, 203-212. https://doi.org/10.1016/j.tifs.2018.09.006

Dragomir, N., and Nicolae, C.G. (2019). Produse inovative - o alternativă în valorificarea ingredientelor BIO [Innovative products - an alternative in valorization on BIO ingredients]. Workshop"Ecologic pentru sănătatea noastră", Bio Life \& Style 2019, Expoziție pentru o viață verde. Bucharest, RO: Ex Terra Aurum \& INVELMultimedia Publishing Houses, ISBN 978-606-764-051-9.

Dragomir, N., Nicolae, C.G., Bujor-Nenița, O.C. (2019). Produse inovative obținute din ingrediente pe bază de fructe și legume ecologice [Innovative products obtained from ingredients based on organic fruits and vegetables]. Catalogul Conferintelor prezentate de USAMV Bucuresti la INDAGRA. Bucharest, RO: Ex Terra Aurum \& INVEL-Multimedia Publishing Houses, ISBN 978-606-764-053-3.

Dragomir, N., Nicolae, C.G., Dragomir V. (2017). Romanian traditional products between local and global. Analele IBNA, 31, 103-111.

Ferreira, M.S.L., Santos, M.C.P., Moro, T.M.A., Basto, G.J., Andrade, R.M.S., Gonçalves, É.C.B.A. (2015). Formulation and characterization of functional foods based on fruit and vegetable residue flour. J. Food Sci. Technol., 52, 822-830. https://doi.org/10.1007/s13197-013-1061-4 http://softfedima.ro/, Retrieved November 22, 2019.

Isbilir, S.S., Sagiroglu, A. (2011). Antioxidant potential of different dill (Anethum graveolens L.) leaf extracts. International Journal of Food Properties, 14(4), 894-902. DOI: 10.1080/10942910903474401

ISO 6658:2005 (2005). Sensory Analysis - Methodology - General guidance. Retrieved December 10, 2019, from https://www.iso.org/standard/36226.html

Jana, S., Shekhawat, G.S. (2010). Anethum graveolens: An Indian traditional medicinal herb and spice. Pharmacognosy Reviews, 4(8), 179-184. DOI: 10.4103/0973-7847.70915.

Kruma, Z., Galoburda, R., Sabovics, M., Gramatina, I., Skudra, I., Dabina-Bicka, I (2011). Aroma composition of microwave vacuum dried dill (Anethum graveolens L.) stems. Procedia Food Science, 1, 1338-1343. doi:10.1016/j.profoo.2011.09.198. 


\section{Current Trends in Natural Sciences}

Vol. 9, Issue 18, pp. 57-63, 2020

https://doi.org/10.47068/ctns.2020.v9i18.009

Current Trends in Natural Sciences (on-line)

ISSN: 2284-953X

Current Trends in Natural Sciences (CD-Rom)

ISSN: 2284-9521

ISSN-L: 2284-9521

ISSN-L: 2284-9521

Najaran, Z.T., Hassanzadeh, M.K., Nasery, M., Emami, S.A. (2016). Dill (Anethum graveolens L.) Oils. In V.R. Preedy, ed, Essential Oils in Food Preservation, Flavor and Safety, (Chapter 45, pp. 405-412). London: Academic Press, London. https://doi.org/10.1016/B978-0-12-416641-7.00045-6

Zeyneb, T.B., Toumi Benali Fawzia, T.B., Mohamed, B., Joon-kwan, M. (2019). Antifungal activity and evaluation of phenolics contents of dill Anethum graveolens L. extracts original from Algeria. Indian Journal of Natural Products and Resources, 10(3), 188-194. 